\title{
Environmental situation in construction, reconstruction and re-profiling of facilities in high-density urban development
}

\author{
Dmitry Topchiy ${ }^{1}$ and Ekaterina Kochurina ${ }^{1, *}$ \\ ${ }^{1}$ Moscow State University of Civil Engineering, Yaroslavskoeshosse, 26, Moscow, 129337, Russia
}

\begin{abstract}
The article studies a set of potential impacts of construction on the environment in the conditions of high-density housing development: the existing buildings, ecological state of water, ground, air and natural components, and the residents of adjacent territories. Given the absence of a compulsory legislative basis regulating the permissibility and limit values of these impacts, the authors propose a comprehensive assessment of the organizational and technological tool that would help reduce the hazardous impact of new construction. Authors have analyzed the foreign experience in improving the environmental safety and comfort in the construction sector and considered the possibility of widespread implementation of certification systems based on local law, which would allow for the problem of the construction impact on the ecological situation to be solved system-wide.
\end{abstract}

\section{Introduction}

When defining the notion of "high-density urban development" as development of a residential area very close to nearby buildings, structures and linear objects located within the zone of influence of new construction or reconstruction, a number of factors hampering the construction work need to be identified. The erection of buildings and structures in such conditions implies a number of destabilizing factors:

- spatial obstacles at a construction site and in the adjacent territory;

- the dimensions of the site's space are limited in width, height, length and depth, which limits the allocation of machinery, roads for vehicles, temporary camp, warehouses, etc;

- the need to remove the section of the developed urban network of engineering communications away from the building spot;

- special parameters for selection of construction machinery for work in special conditions;

- a set of impacts on the environmental situation, including high level of danger for personnel at the construction site and residents of adjacent buildings.

The number of construction sites is constantly increasing in large cities of the Russian Federation, just like anywhere in the world. The new buildings are built with the existing buildings reconstructed or redeveloped. According to the available statistical data from the Department of Nature Management and Environmental Protection of the City of Moscow, the number of complaints against construction sites near the houses of residents in 2016-2017

${ }^{*}$ Corresponding author: ponyjohn@yandex.ru 
increased by $21 \%$ compared to 2015 . The complaints concern excessively high noise levels at night and number of other construction impacts.

The objective of this study is to adapt and develop a set of effective ways allowing construction projects' detrimental effects on the environment to be reduced. These impacts are not addressed in the legislation of the Russian Federation and, therefore, have the greatest destabilizing effect from all the above factors and occur unevenly throughout the entire construction process. Rational use of appropriate technological solutions at the stage of construction allows reducing significant deviations in the environmental impact indicators from the empirical optimum, ensuring ecological safety and comfort of residents in the territory adjacent to the construction site. This creates the need for a numerical assessment of the deterministic and cumulative counter-exposure of these organizational and technological solutions to the anthropological component of the environmental load to determine the implementation effectiveness degree. In addition, a positive effect can be achieved by regulating the application of certain organizational and technological solutions in the form of mandatory environmental program certification adapted to the regional specifics of the Russian Federation.

\section{The impact of construction projects on the environment. Integrated and particular indicators of environmental load}

Based on the experience implementing large-scale construction projects the Russian Federation, the authors drafted a list of the main impacts of construction on the environment broken down into groups. The analysis of available scientific research, carried out by Berezhny A.Y. who used the method of expert assessments, showed that some of these impacts are insignificant and negligible against the background of the ecological situation as a whole (Table 1)[1].

Table 1. The main potential impacts of construction on the environment in high-density urban development.

\begin{tabular}{|l|c|c|c|}
\hline No. & Name of impact group & Example of impact's potential source at the site & Variable \\
\hline 1. & $\begin{array}{c}\text { Acoustic pollution } \\
\text { (noise) }\end{array}$ & $\begin{array}{c}\text { Functioning of the construction machinery's } \\
\text { moving parts }\end{array}$ & $\mathrm{q}_{1}$ \\
\hline 2. & Vibration & $\begin{array}{c}\text { The installation of piles or excavation shoring } \\
\text { supports }\end{array}$ & $\mathrm{q}_{2}$ \\
\hline 3. & Soil pollution* & $\begin{array}{c}\text { Wash-out of concrete mixers in areas not } \\
\text { designated for the purpose. Effects of } \\
\text { construction waste }\end{array}$ & $\mathrm{q}_{3}$ \\
\hline 4. & Water pollution* & Effects of construction waste & $\mathrm{q}_{4}$ \\
\hline 5. & Air pollution & Diesel engines of construction machinery & $\mathrm{q}_{5}$ \\
\hline 6. & $\begin{array}{c}\text { Change in } \\
\text { hydrological regime* }\end{array}$ & $\begin{array}{c}\text { Effects of construction waste } \\
\mathrm{q}_{6}\end{array}$ & $\mathrm{q}_{7}$ \\
\hline 7. & Light pollution* & Illumination of a tower crane with night lights & $\mathrm{q}_{8}$ \\
\hline 8. & $\begin{array}{c}\text { Construction waste } \\
\text { procedure }\end{array}$ & No organized storage zones and disposal \\
\hline 9. & $\begin{array}{c}\text { Electromagnetic } \\
\text { fields* }\end{array}$ & Functioning of construction equipment & $\mathrm{q}_{9}$ \\
\hline
\end{tabular}

* According to the carried out researches it is considered insignificant

The above-mentioned method proposed by A.Y. Berezhny allows determining the degree of the aggregate influence of tangible impacts a construction site has on the environment, which is called the integrated indicator of the environmental load. In this case, it is proposed to bring the study to a differentiated part of the impacted environmental system. This means 
a direct impact of the construction site on a person in the impact zone, so the integrated indicator of environmental load should be complemented with a particular indicator of anthropological ecological load. So, taking into account that the human organism in an important part of the complex ecological environment influenced by various factors of the construction site, we narrow down the calculation from the integrated indicator of environmental load to the particular anthropological index. In this respect, the variety of sources of environmental load will be brought down to three main groups (Tables 2, 3).

Table 2. Anthropological group of environmental load factors.

\begin{tabular}{|c|c|c|c|c|}
\hline Impact nature & $\begin{array}{l}\text { Reference documents } \\
\text { that set the maximum } \\
\text { exposure levels in the } \\
\text { Russian Federation as } \\
\text { of May } 2016\end{array}$ & Impact threshold & $\begin{array}{l}\text { Real impact level at } \\
\text { construction sites in the } \\
\text { Russian Federation }\end{array}$ & Variable \\
\hline $\begin{array}{c}\text { Acoustic } \\
\text { impact (noise) }\end{array}$ & $\begin{array}{l}\text { SN 2.2.4/2.1.8.562-96; } \\
\text { SanPiN 2.2.4.3359-16; } \\
\text { ГOCT 12.1.003-83 }\end{array}$ & $\begin{array}{l}\text { Near buildings in the } \\
\text { daytime - no more than } \\
55 \mathrm{~dB} \text { (at night - } 45 \\
\mathrm{~dB} \text { ); } \\
\text { In apartments - 40dB } \\
\text { and 30dB respectively. }\end{array}$ & $\begin{array}{l}\text { Work of a jackhammer - } \\
120 \mathrm{~dB} \\
\end{array}$ & $\mathrm{q}_{1}^{\mathrm{A}}$ \\
\hline Vibration & $\begin{array}{l}\text { GOST 12.1.012-2004; } \\
\text { SanPiN 2.1.2.2645-10; } \\
\text { SanPiN 2.2.4.3359-16; } \\
\text { SN 2.2.4/2.1.8.566-96 }\end{array}$ & $1,4 \mathrm{~m} / \mathrm{s}^{*} 10^{-2}$ & $\begin{array}{l}\text { Average vibration level } \\
\text { reaches } 4 \mathrm{~m} / \mathrm{s}^{*} 10^{-2} \text {. }\end{array}$ & $\mathrm{q}_{2}^{\mathrm{A}}$ \\
\hline Air pollution & $\begin{array}{c}\text { GN 2.2.5.686-98; } \\
\text { GOST 12.1.007-76; } \\
\text { GOST 12.1.005-88; } \\
\text { GN 2.1.6.2309-07 }\end{array}$ & $\begin{array}{l}\text { For substances of } \\
\text { unidirectional action } \\
\text { MAC } \leq 1\end{array}$ & $\begin{array}{c}\text { The use of diesel engines, } \\
\text { lack of protection from } \\
\text { dust, the production of } \\
\text { electric welding work } \\
\text { MAC } \approx(1,5-2)\end{array}$ & $\mathrm{q}_{3}^{\mathrm{A}}$ \\
\hline
\end{tabular}

Table 3. Anthropological group of environmental load factors and the impact of the above-limit value on the human body.

\begin{tabular}{|l|c|c|c|}
\hline No. & $\begin{array}{c}\text { Impact } \\
\text { type }\end{array}$ & $\begin{array}{c}\text { Biologically acceptable } \\
\text { exposure limit }\end{array}$ & $\begin{array}{c}\text { Biological and mental disorders in the human body at } \\
\text { above-limit values }\end{array}$ \\
\hline 1. & $\begin{array}{c}\text { Acoustic } \\
\text { impact } \\
\text { (noise) }\end{array}$ & $55 \mathrm{~dB}$ (loud speaking) & $\begin{array}{c}\text { At sound levels above } 160 \mathrm{~dB} \text {, the rupture of } \\
\text { eardrums and lungs becomes possible. Noise level of } \\
200 \mathrm{~dB} \text { is lethal. Hearing dullness, laryngitis, memory } \\
\text { and attention impairment, sleep disorder and chronic } \\
\text { fatigue }\end{array}$ \\
\hline 2. & Vibration & $1,4 \mathrm{~m} / \mathrm{s}^{*} 10^{-2} \mathrm{t} \leq 8$ hours & $\begin{array}{c}\text { "Vibration disease" (especially dangerous for the } \\
\text { children's skeleton) }\end{array}$ \\
\hline 3. & $\begin{array}{c}\text { Air } \\
\text { pollution }\end{array}$ & MAC $\leq 1$ & $\begin{array}{c}\text { Injuries of respiratory organs, pneumoconiosis, } \\
\text { acute and chronic poisoning, pneumosclerosis, } \\
\text { bronchial asthma exacerbated, mucosal lesions, } \\
\text { tumors on the skin, suffocation symptoms, } \\
\text { exacerbated pulmonary and nerve diseases. }\end{array}$ \\
\hline
\end{tabular}

\section{Organizational and technological counter-measures}

The heuristic approach to the organizational and technological problems of the environmental safety of construction sites in the Russian Federation is largely attributed to the absence of an obligatory regulatory and technical framework that regulates these issues (Table 2). In the Russian Federation, Federal Law No. 184-FZ of December 27, 2002 "On Technical Regulation" divides the terms "technical regulations" and "standard", therefore, all the 
above-mentioned normative documents became non-mandatory and are applied on a voluntary basis.

On the other hand, systems for the voluntary certification of environmental safety and comfort of construction facilities have been developed and are widely used both in the United States and the U.K. The programs of such certification rating systems (LEED and BREAM, for example) include both architectural and planning, and organizational and technological measures allowing neutralizing the impact of factors harmful to a person in the zone of impact of new construction. So, on the basis of foreign experience, the authors suggest that harmful effects on people at Russian construction sites be minimized by taking a number of similar organizational and technological measures indicated in the widespread certification programs (Table 4).

Table 4. Set of basic organizational and technological measures ensuring the environmental safety requirements in accordance with the main certification systems.

\begin{tabular}{|l|l|c|}
\hline No. & \multicolumn{1}{|c|}{ Organizational and technological measures } & Variable \\
\hline 1. & Drawing up and approval of the plan for construction activities & $\mathrm{t}_{1}^{\mathrm{A}}$ \\
\hline 2. & $\begin{array}{l}\text { Creation of fortifications for the earth, shelter of the earth, earth } \\
\text { embankment }\end{array}$ & $\mathrm{t}_{2}^{\mathrm{A}}$ \\
\hline 3. & Restrictions of construction works at night & $\mathrm{t}_{3}^{\mathrm{A}}$ \\
\hline 4. & Anti-noise shields & $\mathrm{t}_{4}^{\mathrm{A}}$ \\
\hline 5. & Noise protection covers for machinery & $\mathrm{t}_{5}^{\mathrm{A}}$ \\
\hline 6. & Construction of geogrids, tree grills & $\mathrm{t}_{6}^{\mathrm{A}}$ \\
\hline 7. & Deployment of wheel wash-down stations & $\mathrm{t}_{7}^{\mathrm{A}}$ \\
\hline 8. & Creation of traps to capture solid particles & $\mathrm{t}_{8}^{\mathrm{A}}$ \\
\hline 9. & Measures for construction waste removal and treatment & $\mathrm{t}_{9}^{\mathrm{A}}$ \\
\hline 10. & $\begin{array}{l}\text { Reducing emissions from idle construction machinery and } \\
\text { equipment with internal combustion engines }\end{array}$ & $\mathrm{t}_{10}^{\mathrm{A}}$ \\
\hline 11. & Prevention of the impact force from being transmitted to the ground & $\mathrm{t}_{11}^{\mathrm{A}}$ \\
\hline
\end{tabular}

A particular indicator of the ecological load (anthropological component) can be expressed by a matrix of dimensions $3 \times 1$ (formula 1 ).

$$
A=\left[\begin{array}{l}
q_{1}^{A} \\
q_{2}^{A} \\
q_{3}^{A}
\end{array}\right]
$$

The integrated indicator of organizational and technological measures reducing the value of a particular environmental load (impact on a person in the zone affected by a construction site) can also be expressed by a matrix (formula 2).

$$
B=\left[\begin{array}{ccc}
t_{1}^{A} & t_{2}^{A} & t_{3}^{A} \\
t_{4}^{A} & t_{5}^{A} & t_{6}^{A} \\
t_{7}^{A} & t_{8}^{A} & t_{9}^{A} \\
t_{10}^{A} & t_{11}^{A} & t_{n}^{A}
\end{array}\right]
$$

It is assumed that organization the necessary and sufficient complex of organizational and technological measures bring matrices to the form $\mathrm{B} \rightarrow \mathrm{A}$.

\section{Certification systems as a tool for achieving the environmental safety and comfort}


Today, demand is growing globally for resource-saving and energy-efficient construction solutions. In the context of the ever-increasing need for "green construction" (construction of facilities that meet the requirements of environmental safety and comfort of people), a number of leading foreign countries have developed "green standards" that allow construction products to be certified for compliance with the environmental requirements (Table 5).

Table 5. Major international environmental certification rating systems.

\begin{tabular}{|l|c|c|c|c|}
\hline No. & $\begin{array}{c}\text { Name of the voluntary } \\
\text { environmental } \\
\text { certification system }\end{array}$ & $\begin{array}{c}\text { Developer } \\
\text { country }\end{array}$ & $\begin{array}{c}\text { Year of the } \\
\text { development }\end{array}$ & $\begin{array}{c}\text { Number of } \\
\text { internationally } \\
\text { certified facilities as } \\
\text { of 2016 }\end{array}$ \\
\hline 1. & BREEAM & UK & 1990 & $>110,000$ \\
\hline 2. & LEED & U.S. & 1998 & $>4,400$ \\
\hline 3. & CASBEE & Japan & 2001 & $>80$ \\
\hline 4. & GREEN STAR & Australia & 2003 & $>237$ \\
\hline 5. & HK-BREAM & China & 1996 & $>247$ \\
\hline
\end{tabular}

Construction sites in the Russian Federation undergo environmental safety certification as well, but a number of developed programs (for example, ECOPRO and others) are based on the principles and criteria borrowed from widely-adopted foreign analogues, which have been significantly simplified and adapted to suit the Russian economic and construction systems. Voluntary environmental certification, which is commonplace in the leading Western countries, form a set of environmental safety procedures on the basis of "green standards" and other legislative acts of the respective region. These consist of several principal interrelated phases that cover all stages of each investment and construction project (Table 6).

Table 6. Stages of the investment and construction project and the certification program.

\begin{tabular}{|l|c|c|c|}
\hline No. & Stage & $\begin{array}{c}\text { Activities performed by } \\
\text { participants }\end{array}$ & Ecological certification phases \\
\hline 1. & Pre-design stage & $\begin{array}{c}\text { Development of a design; } \\
\text { Feasibility study }\end{array}$ & Preliminary stage \\
\hline 2. & $\begin{array}{c}\text { Detailed design } \\
\text { stage }\end{array}$ & $\begin{array}{c}\text { Detailed design development } \\
\text { Detailed design expert } \\
\text { examination }\end{array}$ & $\begin{array}{c}\text { Design phase - Set of preventive } \\
\text { measures and requirements provided for } \\
\text { in the design documentation }\end{array}$ \\
\hline 3. & $\begin{array}{c}\text { Construction of a a } \\
\text { building or } \\
\text { structure (project } \\
\text { implementation) }\end{array}$ & $\begin{array}{c}\text { Erection of a building or structure } \\
\text { Obtaining the report on conformity }\end{array}$ & $\begin{array}{c}\text { Technological stage - organizational and } \\
\text { technological measures reducing the } \\
\text { impact of construction on the } \\
\text { environment. Monitoring }\end{array}$ \\
\hline 4. & $\begin{array}{c}\text { Commissioning of } \\
\text { a building }\end{array}$ & $\begin{array}{c}\text { Creation of a working commission } \\
\text { for the acceptance of the facility. } \\
\text { Integrated testing of engineering } \\
\text { systems }\end{array}$ & $\begin{array}{c}\text { Certification of finished construction } \\
\text { products }\end{array}$ \\
\hline 5. & $\begin{array}{c}\text { Operational stage } \\
\text { Technical operation of a building } \\
\text { or structure, engineering systems, } \\
\text { adjacent territory }\end{array}$ & $\begin{array}{c}\text { Analysis of solutions for technical } \\
\text { operation of buildings and structures }\end{array}$ \\
\hline
\end{tabular}

A construction site's environmental certification procedure is a documentary confirmation of the site's compliance with the necessary criteria for the selected rating system based on the evaluation of the expert certification group that works throughout the investment and construction project life.

The choice of a specific system depends on the number of features of the certified construction site, as well as on the current stage of the investment and construction project 
where the certification program is to be implemented. Advantages and disadvantages of each system are described in a number of existing scientific works of foreign authors and are aggregated according to the basic established criteria (Table 7)[2].

Table 7. Comparative analysis of major environmental rating systems.

\begin{tabular}{|c|c|c|c|c|c|c|c|c|c|}
\hline 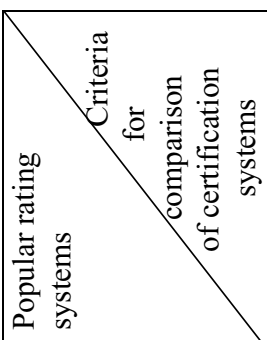 & 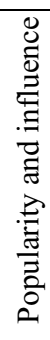 & 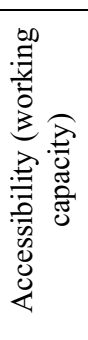 & 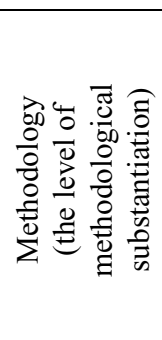 & 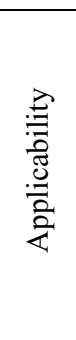 & 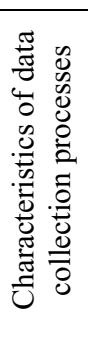 & 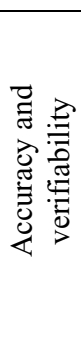 & 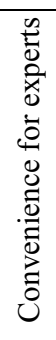 & 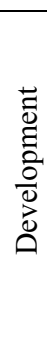 & 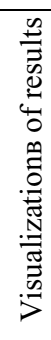 \\
\hline BREEAM & 10 & 7 & 11 & 13 & 7 & 8 & 8 & 8 & 3 \\
\hline LEED & 10 & 7 & 10 & 13 & 7 & 7 & 10 & 8 & 3 \\
\hline CASBEE & 6 & 7 & 13 & 11,5 & 6 & 9 & 6 & 7 & 4 \\
\hline GREEN STAR & 5 & 8 & 9 & 10 & 9 & 5 & 8 & 8 & 3 \\
\hline HK-BREAM & 5 & 8 & 11 & 9 & 8 & 5 & 8 & 8 & 4 \\
\hline
\end{tabular}

The study results (Table 7) suggest that the American LEED certification system and the British BREEAM system are the most effective. In actual fact, these systems are the most widely applied, too (Fig. 1).

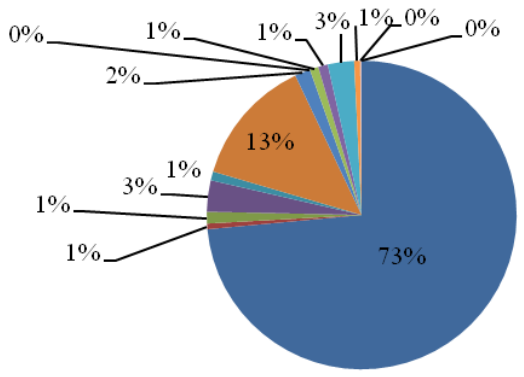

- North America
-South America
-Southern Europe
Eastern Europe
$\square$ Western Asia
$\square$ Eastern Asia
Australia and New Zealand

$\square$ Central America and the Carribean
$\square$ Western Europe
$\square$ Northern Europe
$\square$ Central Asia
$\square$ Southern Asia
$\square$ South-Eastern Asia
$\square$ Africa

Fig. 1. The quantitative ratio of certified sites worldwide between the LEED and BREEAM rating systems.

Taking into account the fact that the existing construction regulatory and technical framework in the Russian Federation does not stipulate a set of necessary and sufficient requirements to ensure environmental safety and comfort of the participants in the construction process and users of the finished construction products, the authors propose the use of these systems as an organizational and technological tool for environmental safety. Certification according to world-recognized systems LEED or BREEAM (depending on the site conditions) will provide a set of environmental safety measures from the design project to the stage of technical operation. 
A large number of sites certified outside of Russia (Fig. 1) is attributed to the fact that the compliance with the requirements of these rating systems can be achieved through taking a number of organizational and technological decisions that require additional resources. Russian contractors often try to save on such resources. The construction market in Russia is highly competitive, and customers opt for the shortest deadlines and minimum cost when choosing a contractor. To meet these two conditions, contractors might just economize heavily on resources not provided for by the regulatory and technical framework of the Russian Federation as mandatory.

Let us consider a numerical estimation of sufficiency of performance of a number of mandatory and non-mandatory measures carried out at some construction sites during construction and installation works using the effectiveness assessing scale developed by A.Y. Berezhniy that influence the ecological situation. The scale evaluates 6 criteria identified by experts as the most significant:

1) Atmospheric pollution: $0,1,2,3$ points ( 3 points - maximum measures of minimize).

2) Noise: $0,1,2,3$ points ( 3 points - maximum measures of minimize).

3) Construction waste: $0,1,2,3$ points ( 3 points - maximum measures of minimize).

4) Soil pollution: 0.1 point ( 1 point - maximum measures of minimize).

5) Household waste: $0,1,2,3$ points ( 3 points - maximum measures of minimize).

6) Sanitary zones - 0,1,2 points (2 - maximum measures of minimize).

Now, let us compare the sufficiency of the implementation of organizational and technological solutions aimed at minimizing the influence of harmful factors from the construction and installation works using the efficiency rating scale for objects that have passed certification according to the criteria of environmental rating systems and facilities constructed according to the requirements stipulated in the regulatory and technical framework of the Russian Federation (Table 8).

Table 8. Estimating the sufficiency of measures at the construction sites in the Russian Federation.

\begin{tabular}{|c|c|c|c|c|c|c|c|c|c|}
\hline \multirow[b]{2}{*}{$\dot{\imath}$} & \multirow[b]{2}{*}{$\begin{array}{c}\text { Name of } \\
\text { certified/uncertified facility }\end{array}$} & \multirow{2}{*}{$\begin{array}{c}\text { LEED, } \\
\text { BREEAM, } \\
\text { Russian } \\
\text { Safety } \\
\text { Norms(RSN) }\end{array}$} & \multirow[b]{2}{*}{$\begin{array}{l}\text { Location of } \\
\text { the facility } \\
\text { (city) }\end{array}$} & \multicolumn{6}{|c|}{$\begin{array}{c}\text { Points of the impact of harmful } \\
\text { production factors }\end{array}$} \\
\hline & & & & 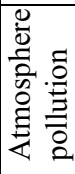 & $\begin{array}{l}0 \\
\frac{m}{0} \\
z\end{array}$ & 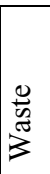 & $=$ & 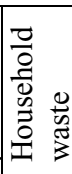 & 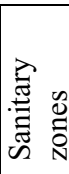 \\
\hline 1 & Business-center Dukat Place & BREEAM & Moscow & 3 & 3 & 3 & 1 & 3 & 2 \\
\hline 2 & $\begin{array}{l}\text { Production facility of Hamilton } \\
\text { Standard-Nauka }\end{array}$ & LEED & Kimry & 3 & 3 & 3 & 1 & 3 & 2 \\
\hline 3 & Shopping center $\mathrm{R}$ & $R S N$ & $\begin{array}{l}\text { St. } \\
\text { Petersburg }\end{array}$ & 0 & 1 & 3 & 0 & 3 & 2 \\
\hline 4 & Residential complex N & $R S N$ & Moscow & 1 & 1 & 3 & 0 & 2 & 2 \\
\hline 5 & Sports Complex M & $R S N$ & Moscow & 1 & 1 & 3 & 1 & 3 & 2 \\
\hline
\end{tabular}

Despite the fact that the submitted criteria were determined by the expert group as the most harmful for the environment, the measures to reduce the impact of these factors were fully implemented only if the requirements for certification for environmental rating systems were achieved. Environmental requirements for facilities built only according to the requirements of the regulatory and technical framework of the Russian Federation were not met in full due to the absence of mandatory requirements. The following significant anthropological factors should also be taken into account when assessing the effectiveness of organizational and technological solutions in construction in high-density building conditions:

- vibration in the areas adjacent to construction sites;

- light pollution at night. 
These criteria are significant for residents living in close proximity to construction sites, and are considered by such rating systems as BREEAM and LEED.

\section{Conclusion}

Pursuant to Article 21 of the Constitution of the Russian Federation and Article 5 of the Universal Declaration of Human Rights, a man's life is inviolable and may not be exposed to harm even of unintentional nature. The methodology for ensuring the safety of life and health of people in the zone of influence of construction sites proposed in this article implies an evaluation-based analysis of the detrimental impact of the construction site using the environmental load indicators per the developed methodology. We also propose a set of effective countermeasures of organizational and technological nature introduced through wide application of internationally certified environmental programs across the Russian construction sites.

\section{References}

1. A.A. Lapidus, A.Y. Berezhniy, Proceedings Vestnik MGSU, 1997-0935 (2012)

2. B. K. Nguyena, H.Altana, Procedia Engineering, 1877-7058 (2011)

3. M.Y. Slesarev, T.V. Kuzovkina, Ecology of urbanized territories, 1816-1863 (2014)

4. S.V. Sokolov, V.N. Sedih, S.V. Novikov, V.V. Aleksashina, BST, 0007-7690 (2011)

5. V. Leonov, V. Denisov, V. Sedykh, S. Novikov, BST, 0007-7690 (2012)

6. A.L. Bolsherotov, Zhilishchnoye stroitel'stvo, 0044-4472 (2011) 